\title{
Effect of Microelectric Current and Other Activation Techniques on Dissolution Abilities of Sodium Hypochlorite at Different Temperatures in Bovine Tissues: An in vitro Study
}

\author{
${ }^{1}$ Shemil M Sha, ${ }^{2}$ Sajeena Narayanan, ${ }^{3}$ Baji Babu, ${ }^{4}$ Rajesh Pillai, ${ }^{5}$ Nettiyat O Varghese, ${ }^{6}$ Afzal A Salim, ${ }^{7}$ Abe Antony
}

\begin{abstract}
Aim: To study the effects of microelectric current and other methods at different temperatures, on the dissolution of sodium hypochlorite $(\mathrm{NaOCl})$.
\end{abstract}

\begin{abstract}
Materials and methods: Bovine muscle tissues $(n=165)$ were prepared and grouped into three temperature groups: (1) Room temperature, (2) $45^{\circ} \mathrm{C}$, and (3) $600^{\circ} \mathrm{C}$. Each temperature group was divided into five subgroups: (i) Control group: $5.25 \% \mathrm{NaOCl}$; (ii) $5.25 \% \mathrm{NaOCl}$ with pipetting; (iii) $5.25 \% \mathrm{NaOCl}$ with sonic activation; (iv) $5.25 \% \mathrm{NaOCl}$ with ultrasonic activation; and (v) $\mathrm{E}-\mathrm{NaOCl}=5.25 \% \mathrm{NaOCl}$ with microelectric current. Weight of specimens before and after treatment was done. In each group average, standard deviation and median were found out. The data were analyzed using multiway analysis of variance (ANOVA) test and Tukey honestly significant difference (HSD) tests. The alpha-type error was set at $<0.05$.
\end{abstract}

Results: Tissue dissolution was highest with the ultrasonic group ( $p<0.05$ ), and the tissue dissolution ability of other groups was significantly higher than the positive control $(p<0.05)$ at room temperature. $\mathrm{E}-\mathrm{NaOCl}$ group dissolved greater quantity of tissue $(p<0.05)$ at $45^{\circ} \mathrm{C}$ and at $60^{\circ} \mathrm{C}$.

Conclusion: $\mathrm{NaOCl}$ used along with microelectric current produced a higher tissue-dissolving ability. Combining with other techniques provides a synergistic effect on tissue dissolution.

Keywords: Microelectric current, Sodium hypochlorite, Temperature, Tissue dissolution.

How to cite this article: Sha SM, Narayanan S, Babu B, Pillai R, Varghese NO, Salim AA, Antony A. Effect of Microelectric Current and Other Activation Techniques on Dissolution Abilities of Sodium Hypochlorite at Different Temperatures in Bovine Tissues: An in vitro Study. Cons Dent Endod J 2018;3(1):1-5.

Source of support: Nil

Conflict of interest: None

\footnotetext{
${ }^{1-3}$ Postgraduate Student, ${ }^{4}$ Professor and Head, ${ }^{5}$ Principal ${ }^{6}$ Professor, ${ }^{7}$ Senior Lecturer

${ }^{1-7}$ Department of Conservative Dentistry and Endodontics, PMS Dental College of Science \& Research, Thiruvananthapuram Kerala, India

Corresponding Author: Shemil M Sha, Postgraduate Student Department of Conservative Dentistry and Endodontics, PMS Dental College of Science \& Research, Thiruvananthapuram Kerala, India, e-mail: shashemil05@gmail.com
}

\section{INTRODUCTION}

Microorganisms and their products cause the development of pulp and periradicular pathology. ${ }^{1}$ Sodium hypochlorite solution is the mostly used irrigant due to its tissue-dissolving and antimicrobial abilities. ${ }^{2}$

The tissue-dissolving capacity depends on time of exposure of the solution, concentration, volume, and the surface area of the tissue it acts upon. ${ }^{3}$ Methods to increase the extent of tissue dissolution are: Increasing the solution $\mathrm{pH}$, and by increasing the temperature, ultrasonic activation, elongated working time, and by continuous agitation of the solution. ${ }^{4-6}$ Pécora et $\mathrm{al}^{7}$ studied the "dynamic balance" of $\mathrm{NaOCl}: \mathrm{NaOCl}+\mathrm{H}_{2} \mathrm{O}$ $=\mathrm{NaOH}+\mathrm{HOCl}=\mathrm{Na}^{+}+\mathrm{OH}^{-}+\mathrm{H}^{+}+\mathrm{OCl}^{-}$. The results of dynamic balance of $\mathrm{NaOCl}$ were amino acid neutralization, saponification, and chloramination reaction. ${ }^{8,9}$

Safe and effective irrigations, such as EndoActivator (EA) and ultrasound were helped by Irrigation devices and techniques. The EA has a noncutting polymer tip. It is vibrated using sonic energy to achieve vigorous agitation of irrigation solutions. ${ }^{10,11}$ Passive ultrasonic irrigation (PUI) produces ultrasonic waves to an irrigant.

Growing bubbles produced by ultrasonic energy collapse and the pressure-vacuum effect created contribute to the bactericidal effect. Passive ultrasonic irrigation instrument through its oscillation creates a resonance that agitates the irrigant what is called stable cavitation. An acoustic streaming ${ }^{12}$ produced by the combination of these effects enhances the cleaning and decontamination effect of the irrigant. ${ }^{13}$ When $\mathrm{NaOCl}$ is used along with PUI, due to the ultrasound effect ${ }^{3,14}$ its organic tissue-dissolving and antibacterial efficacy is enhanced. In electrolysis, a direct electric current by a potentiostat/ galvanostat is used. ${ }^{15}$ During activation, liquids turn into a metastable state. As a result, chemical structure, the hydrogen concentration, and oxidation reduction potential of these liquids change. ${ }^{16}$ Ertugrul et al ${ }^{17}$ showed that $\mathrm{NaOCl}$ which is microelectrically activated increases the tissue dissolution capacity.

This was an in vitro study conducted in bovine tissues to compare microelectric current activation and other methods, on dissolution capabilities of $\mathrm{NaOCl}$ at different temperatures. 


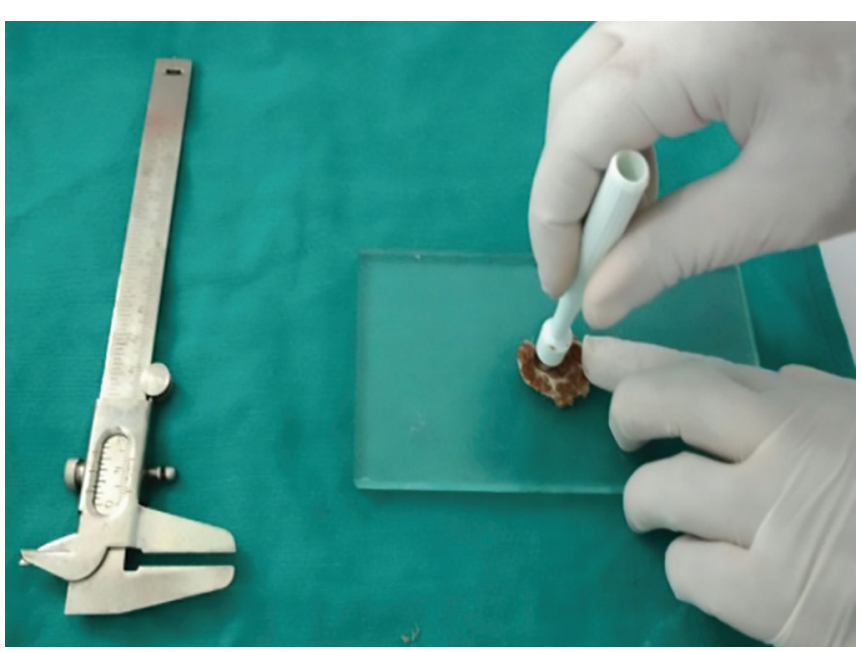

Fig. 1: Specimen collection

\section{MATERIALS AND METHODS}

The specimen in the study was bovine muscle tissue got from a local butcher shop. $\mathrm{NaOCl}$ solution, (5.25\% chlorine) was used and stored $\left(+4^{\circ} \mathrm{C}\right)$. Bovine muscle tissue stored at $16^{\circ} \mathrm{C}$ in a $100 \%$ humid medium. Standardization of size and weight was performed by using a biopsy punch with a 6-mm diameter to collect the samples from a 2-mm tissue (Fig. 1), and weighing of samples was done with an electronic microbalance prior to the testing (Fig. 2).

Mean weight of tissue samples before treatment with $\mathrm{NaOCl}$, was $58 \mathrm{mg}$. Similar to a study by Stojicic et al, ${ }^{6}$ the experiments were performed at 3 different temperatures: room temperature $\left(28^{\circ} \mathrm{C}\right), 45^{\circ} \mathrm{C}$, and $60^{\circ} \mathrm{C}$. Containers in an acclimatized room is used to do experiments at room temperature.

For those experiments conducted at $45^{\circ} \mathrm{C}$ and at $60^{\circ} \mathrm{C}$, a temperature-controlled water bath was used and an external thermometer was used to confirm the temperature. Each temperature group was then sub divided into five subgroups by different activation methods.

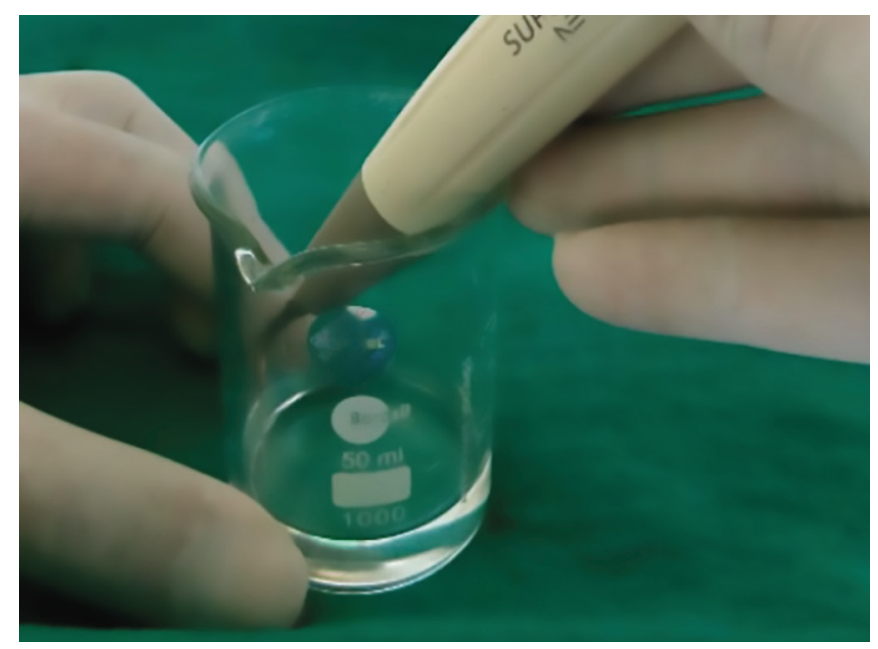

Fig. 3: Ultrasonic activation

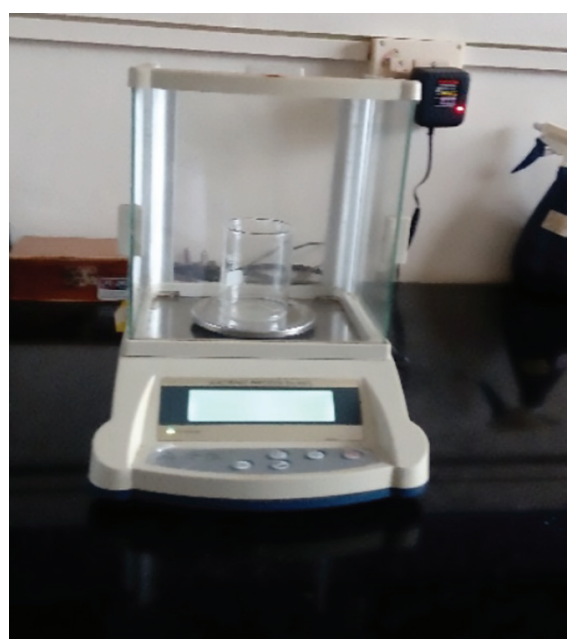

Fig. 2: Microelectric balance

Table 1: Groups of bovine muscle tissues studied

\begin{tabular}{llll}
\hline \multicolumn{3}{l}{ Room temperature } & \\
$n$ & group & $45^{\circ} \mathrm{C}$ group & $60^{\circ} \mathrm{C}$ group \\
\hline 11 & $\mathrm{NaOCl}$ & $\mathrm{NaOCl}$ & $\mathrm{NaOCl}$ \\
11 & Pipetting & Pipetting & Pipetting \\
11 & Sonic activation & Sonic activation & Sonic activation \\
11 & Ultrasonic & Ultrasonic & Ultrasonic \\
& activation & activation & activation \\
11 & E-NaOCl & E- NaOCl & E-NaOCl \\
\hline
\end{tabular}

Total sample contained 165 tissue samples, 11 in each group (Table 1). For each sample, the duration of the experiment conducted was 5 minutes.

The control group was $5.25 \% \mathrm{NaOCl}$ solution without any activation. For the ultrasonic activation, stainless steel size of \#25 ultrasonic tip was used which was operated at a moderate speed in the solution (Fig. 3).

The sonic activation was done with EA (polymer tip no. 25/04) which was run at about 10,000 cycles per minute (Fig. 4).

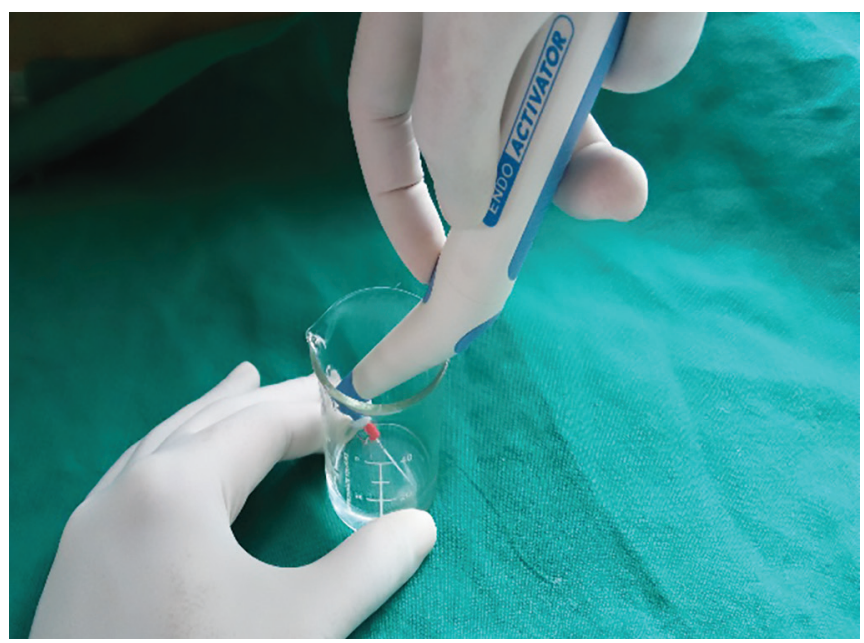

Fig. 4: Sonic activation 


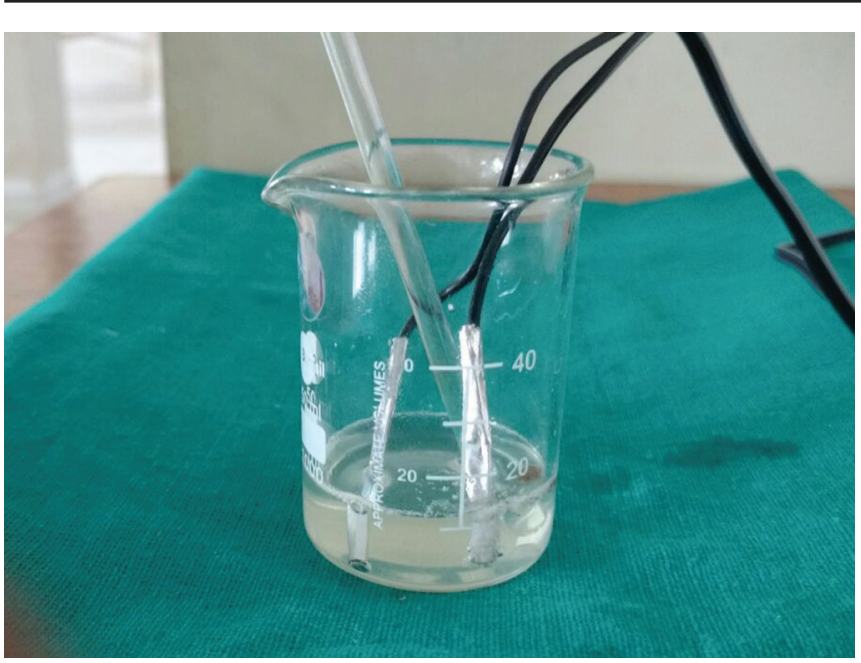

Fig. 5: Microelectric current activation

For the ultrasonic and sonic activation, the tips were activated $6 \mathrm{~mm}$ from the tissue after submerging up to $10 \mathrm{~mm}$ in the $5.25 \% \mathrm{NaOCl}$ solution.

In conforming to a study done by Stojicic et al, ${ }^{6}$ pipetting was done with a glass rod which was mechanically activated $6 \mathrm{~mm}$ from the tissue. In the microelectric methods, a potentiometer was calibrated to provide 10 $\mathrm{mA}$ and $3 \mathrm{~V}$ to the $\mathrm{NaOCl}$. Current activation was done for 15 seconds each minute for the 5 minute period (Fig. 5).

After 5 minutes, each sample was taken out, gently dried, and again weighed. Weight lost was calculated in percentage.

\section{Statistical Analysis}

Data were statistically analyzed using multi-way ANOVA and Tukey HSD test. The alpha-type error was at $<0.05$.

\section{RESULTS}

For each of the group, standard deviation and mean were calculated. All activation groups were dissolved a higher amount of tissue than the control groups $(\mathrm{p}<0.05)$. Table 2 shows that at the room temperature, ultrasonic group dissolved a higher amounts of tissue followed by

Table 2: The effect of various methods of activation on tissue dissolution (percentage of tissue weight change loss \pm SD) at various temperatures

\begin{tabular}{llll}
\hline $\begin{array}{l}\text { Activation } \\
\text { techniques }\end{array}$ & $\begin{array}{l}\text { Room temperature } \\
\text { (mean \% loss of } \\
\text { mass } \pm \mathrm{SD} \text { ) }\end{array}$ & $\begin{array}{l}\text { At } 45^{\circ} \mathrm{C} \\
\text { (mean \% loss } \\
\text { of mass } \pm S D \text { ) }\end{array}$ & $\begin{array}{l}\text { At } 60^{\circ} \mathrm{C} \\
\text { (mean } \% \text { loss } \\
\text { of mass } \pm S D \text { ) }\end{array}$ \\
\hline $\mathrm{NaOCl}$ & $2.6 \pm 0.133^{\mathrm{a}}$ & $5.26 \pm 0.11^{\mathrm{d}}$ & $6.89 \pm 0.18^{\mathrm{c}}$ \\
Pipetting & $2.59 \pm 0.162^{\mathrm{a}}$ & $5.27 \pm 0.10^{\mathrm{d}}$ & $6.87 \pm 0.16^{\mathrm{c}}$ \\
Sonic & $3.46 \pm 0.07^{\mathrm{b}}$ & $6.14 \pm 0.03^{\mathrm{e}}$ & $6.91 \pm 0.19^{\mathrm{c}}$ \\
Ultrasonic & $6.88 \pm 0.162^{\mathrm{c}}$ & $12.04 \pm 0.01^{\mathrm{f}}$ & $15.54 \pm 0.10^{\mathrm{h}}$ \\
E-NaOCl & $5.28 \pm 0.11^{\mathrm{d}}$ & $13.6 \pm 0.18^{\mathrm{g}}$ & $19.7 \pm 0.27^{\mathrm{t}}$ \\
\hline
\end{tabular}

SD: Standard deviation

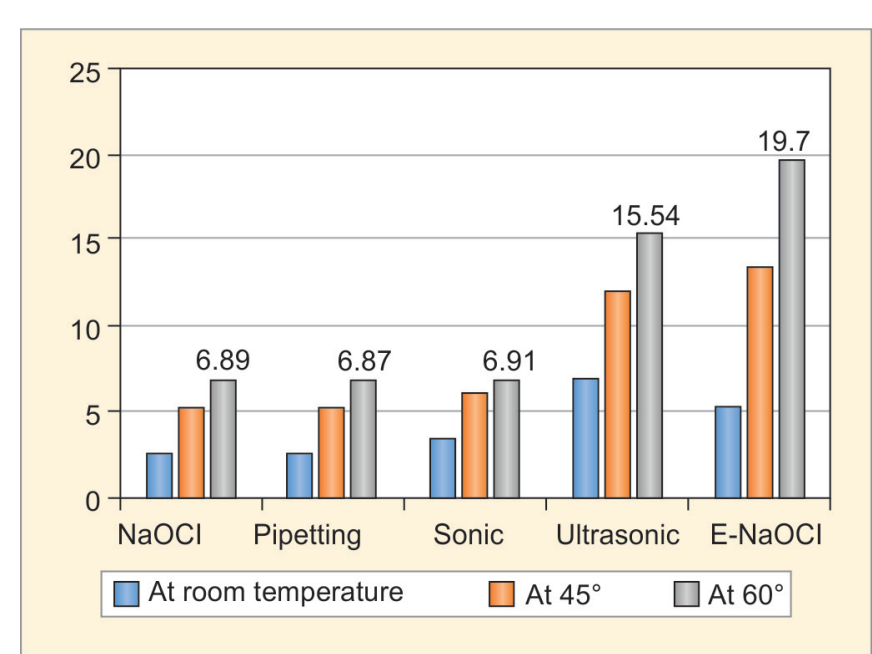

Graph 1: Bar chart showing the relative amounts of loss of mass ( $n=11$ in each group) after using various activation methods

$\mathrm{E}-\mathrm{NaOCl}$ and sonic activation $(\mathrm{p}<0.05)$. There was not much difference in the mean percentage loss between the control and pipetting groups (Table 2).

At $45^{\circ} \mathrm{C}$, there was not much difference in the mean percentage loss between control and pipetting group and at $60^{\circ} \mathrm{C}$, there was not much difference in the mean percentage loss between the control, pipetting, and sonic groups $(\mathrm{p}<0.05)$.

At $45^{\circ} \mathrm{C}$ and at $60^{\circ} \mathrm{C}$, the E-NaOCl group showed superior dissolution ability than any other groups $(\mathrm{p}<0.05)$. As the bar diagram shows, subgroups at $60^{\circ} \mathrm{C}$ showed a much higher dissolution ability followed by subgroups at $45^{\circ} \mathrm{C}$ and at room temperature $(\mathrm{p}<0.05)$ (Graph 1).

\section{DISCUSSION}

Several studies have been demonstrated on the dissolution property of $\mathrm{NaOCl}$. This study emphasized the effect of activation of $\mathrm{NaOCl}$ at different temperatures on the bovine muscle tissue. The agitation method increases the $\mathrm{NaOCl}^{\prime}$ s dissolution effect. ${ }^{3,6,18,19}$ Various tissues have been used by previous tissue dissolution studies including bovine pulp, ${ }^{20}$ muscle tissue of porcine,${ }^{21}$ rabbit liver, ${ }^{22}$ connective tissue of rat, ${ }^{3}$ and the oral mucosa of pig. ${ }^{18}$ Instead of pulp tissue, bovine muscle tissues were chosen as a specimen so as to standardize both weight and surface area.

Although there are many literatures supporting the importance of activation methods on increasing the tissue dissolution property of $\mathrm{NaOCl}$, there are only few studies on the microelecric activation of $\mathrm{NaOCl}$ solution. The present study proved that the microelectric activation of $\mathrm{NaOCl}$ has superior results when compared with other activation methods. Pronounced improvement in the dissolution ability was seen when heated above room temperature. 
In the current study, $\mathrm{NaOCl}$ was heated at $45^{\circ} \mathrm{C}$ and $60^{\circ} \mathrm{C}$ and the results proved that the dissolution ability of warmed $\mathrm{NaOCl}$ was found to be superior on increasing the temperature irrespective of any activation method, which was similar to the results obtained by other previous studies. ${ }^{23-25}$

Conventional agitation method like ultrasonic was tested in the group. At room temperature, ultrasonic activation produced a faster dissolution ability $(\mathrm{p}<0.05)$, which was inconsistent with the results obtained in another study. ${ }^{27}$ Microelectric activation of $\mathrm{NaOCl}$ produced an improved tissue dissolution ability when compared with sonic activation and pipetting $(\mathrm{p}<0.05)$, contradicting the previous study. ${ }^{26}$ Some previous studies have shown that ultrasonic-activated $\mathrm{NaOCl}$ cleaned root canals successfully. ${ }^{25}$

However, other researchers found no difference in the syringe irrigation of the root canal between ultrasonic and conventional methods. ${ }^{27-29}$ The difference in results may be linked to the concentration of $\mathrm{NaOCl}$, volume, power setting, and the duration of treatment with activation.

A positive combination results on $\mathrm{NaOCl}$ activated with heat, microelectric current and agitation methods on $\mathrm{NaOCl}^{\prime}$ s tissue-dissolving ability were obtained. The present study found not much difference between the control groups, sonic activation, and pipetting, which confirms those found by Stojicic et al. ${ }^{6}$

In previous studies, electrolyzed water was used as a canal washing solution. ${ }^{30,31}$ In the present study, a potentiometer was set to supply $10 \mathrm{~mA}$ and $3 \mathrm{~V}$ to the $\mathrm{NaOCl}$ solution to change the dynamic structure of $\mathrm{NaOCl}$, and the direct current was passed through the $\mathrm{NaOCl}$ solution at a micro level. The current value used here is tolerable for human beings according to the standard. ${ }^{32}$ However, the methodology differed from previous studies which used electrolyzed water. The results obtained may not be directly implicated to the clinical conditions; however, a direct current applied with a suitable potentiometer provides a faster tissue-dissolving capacity with the performance similar to a preheated $\mathrm{NaOCl}$.

This activation method can be used in combination with other conventional activation systems, such as EA or ultrasonics during the final stage of irrigation.

\section{CONCLUSION}

Within the limitations of the study, the dissolution ability of the $\mathrm{NaOCl}$ can be increased effectively by the combined use of microelectric energy, heat, and other techniques like ultrasonic, sonic, and pipetting.

\section{CLINICAL SIGNIFICANCE}

It has to be noted that the current study was performed in an in vitro study model and is not directly estimated with clinical conditions. However, further studies should be conducted on the activation of $\mathrm{NaOCl}$ with microelectric energy to better understand this technique in practice, and its the effect on the functioning of pace makers should also be well studied. Since the current value used in the study is tolerable for human beings according to the standard and the results obtained is far much desirable, it paves the way for a promising future in the field of irrigation.

\section{REFERENCES}

1. Kakehashi S, Stanley HR, Fitzgerald RJ. The effects of surgical exposures of dental pulps in germ-free and conventional laboratory rats. Oral Surg Oral Med Oral Pathol 1965 Sep;20: 340-349.

2. Haapasalo M, Shen $Y$, Wang Z, Gao Y. Irrigation in endodontics. Br Dent J 2014 Mar;216(6):299-303.

3. Moorer WR, Wesselink PR. Factors promoting the tissue dissolving capability of sodium hypochlorite. Int Endod J 1982 Oct;15(4):187-196.

4. Jungbluth H, Marending M, De-Deus G, Sener B, Zehnder M. Stabilizing sodium hypochlorite at high $\mathrm{pH}$ : effects on soft tissue and dentin. J Endod 2011 May;37(5):693-696.

5. Zehnder M. Root canal irrigants. J Endod 2006 May;32(5): 389-398.

6. Stojicic S, Zivkovic S, Qian W, Zhang H, Haapasalo M. Tissue dissolution by sodium hypochlorite: Effect of concentration, temperature, agitation, and surfactant. J Endod 2010 Sep;36(9):1558-1562.

7. Pécora, JD.; Sousa-Neto, MD.; Estrela, C. Soluçõesirrigadorasauxiliares do preparo do canal radicular. In: Estrela C, Figueiredo JA, editors. Endodontia-Princípiosbiológicos e mecânicos. São Paulo: ArtesMédicas; 1999. pp. 552-569.

8. Spanó JC, Barbin EL, Santos TC, Guimarães LF, Pécora JD. Solvent action of sodium hypochlorite on bovine pulp and physico-chemical properties of resulting liquid. Braz Dent J 2001 Feb;12(3):154-157.

9. Estrela C, Estrela CR, Barbin EL, Spanó JC, Marchesan MA, Pécora JD. Mechanism of action of sodium hypochlorite. Braz Dent J 2002 Feb;13(2):113-117.

10. Brito PR, Souza LC, Machado de Oliveira JC, Alves FR, De-Deus G, Lopes HP, Siqueira JF Jr. Comparison of the effectiveness of three irrigation techniques in reducing intracanal Enterococcus faecalis populations: an in vitro study. J Endod 2009 Oct;35(10):1422-1427.

11. Pasqualini D, Cuffini AM, Scotti N, Mandras N, Scalas D, Pera F, Berutti E. Comparative evaluation of the antimicrobial efficacy of a $5 \%$ sodium hypochlorite subsonic-activated solution. J Endod 2010 Aug;36(8):1358-1360.

12. Martin H, Cunningham W. Endosonic endodontics: the ultrasonic synergistic system. Int Dent J 1984 Sep;34(3): 198-203.

13. Basrani, B. Endodontic irrigation: chemical disinfection of the root canal system. Switzerland: Springer International Publishing AG; 2015.

14. deAlmeidaAP, Souza MA, MiyagakiDC, Dal Bello Y,Cecchin D, Farina AP. Comparative evaluation of calcium hypochlorite and sodium hypochlorite associated with passive ultrasonic 
irrigation on antimicrobial activity of a root canal system infected with Enterococcus faecalis: an in vitro study. J Endod 2014 Dec;40(12):1953-1957.

15. Kreuter W, Hofmann H. Electrolysis: the important energy transformer in a world of sustainable energy. Int J Hydrogen Energy 1998 Aug;23(8):661-666.

16. Bakhir, VM.; Spector, LE.; Zadorozhny, YG.; Lysenko, NM.; Rudinsky, YA. A device for electrochemical treatment of liquids. USSR Certificate of Authorship no. 1719316; 1989.

17. Ertugrul IF, Maden M, Orhan EO, Ozkorucuklu SP, Aglarca AV. Rapid tissue dissolution efficiency of electrically activated sodium hypochlorite on bovine muscle. Eur J Dent 2014 OctDec;8(4):464-468.

18. Hand RE, Smith ML, Harrison JW. Analysis of the effect of dilution on the necrotic tissue dissolution property of sodium hypochlorite. J Endod 1978 Feb;4(2):60-64.

19. Turkun M, Cengiz T. The effects of sodium hypochlorite and calcium hydroxide on tissue dissolution and dissolution and root canal cleanliness. Int Endod J 1997 Sep;30(5):335-342.

20. Mohammadi Z, Shalavi S, Jafarzadeh H. Ethylenediaminetetraacetic acid in endodontics. Eur J Dent 2013 Sep;7(Suppl 1): S135-S142.

21. Okino LA, Siqueira EL, Santos M, Bombana AC, Figueiredo JA. Dissolution of pulp tissue by aqueous solution of chlorhexidine digluconate and chlorhexidine digluconate gel. Int Endod J 2004 Jan;37(1):38-41.

22. Christensen CE, McNeal SF, Eleazer P. Effect of lowering the $\mathrm{pH}$ of sodium hypochlorite on dissolving tissue in vitro. J Endod 2008 Apr;34(4):449-452.

23. Abou-Rass M, Oglesby SW. The effects of temperature, concentration, and tissue type on the solvent ability of sodium hypochlorite. J Endod 1981 Aug;7(8):376-377.
24. Rossi-Fedele G, De Figueiredo JA. Use of a bottle warmer to increase $4 \%$ sodium hypochlorite tissue dissolution ability on bovine pulp. Aust Endod J 2008 Apr;34(1):39-42.

25. Ahmad M, Pitt Ford TJ, Crum LA. Ultrasonic debridement of root canals: acoustic streaming and its possible role. J Endod 1987 Oct;13(10):490-499.

26. Ertuğrul IF, Maden M, Orhan EO, Özkorucuklu SP. The effect of micro-electric current and other activation techniques on dissolution abilities of sodium hypochlorite in bovine tissues. BMC Oral Health 2015 Dec;15:161.

27. Cymerman JJ, Jerome LA, Moodnik RM. A scanning electron microscope study comparing the efficacy of hand instrumentation with ultrasonic instrumentation of the root canal. J Endod 1983 Aug;9(8):327-331.

28. Mayer BE, Peters OA, Barbakow F. Effects of rotary instruments and ultrasonic irrigation on debris and smear layer scores: a scanning electron microscopic study. Int Endod J 2002 Jul;35(7):582-589.

29. Tauber R, Morse DR, Sinai IA, Furst ML. A magnifying lens comparative evaluation of conventional and ultrasonically energized filing. J Endod 1983 Jul;9(7):269-274.

30. Qing Y, Akita Y, Kawano S, Kawazu S, Yoshida T, Sekine I. Cleaning efficacy and dentin micro-hardness after root canal irrigation with a strong acid electrolytic water. J Endod 2006 Nov;32(11):1102-1106.

31. Solovyeva AM, Dummer PM. Cleaning effectiveness of root canal irrigation with electrochemically activated anolyte and catholyte solutions: a pilot study. Int Endod J 2000 Nov;33(6):494-504.

32. German Institute for Standardization. Effects of current on human beings and livestock-part I: general aspects. Frankfurt: DIN German Institute for Standardization; 2005. p. 59. 